THURSDAY, MARCH $28, \quad 1878$

SCIENTIFIC WORTHIES

XII.-William HaRvey, ${ }^{1}$ BORN ApriL I, 1578, DIED JUNE 3, 1658

W

ILLIAM HARVEY was born three hundred years ago, on the first of April, 1578, at Folkestone, in

Kent. He was the eldest son of his fatber; who seems to have been a substantial farmer, wealthy enough to send his eldest son to the university and to embark his five other male children in the mercantile pursuits in which they all acquired riches. At sixteen, Harvey was sent to Caius College, Cambridge, and graduated B.A. at nineteen. But, desiring to become a physician, Harvey wisely determined to proceed with his medical studies at one of the great continental seats of learning; and, by good hap, chose the University of Padua, which had been famous for a long succession of admirable anatomists, among them Vesalius and Fabricius of Aquapendente, who was the incumbent of the anatomical chair in Harvey's time.

After five years' study at Padua, Harvey took his doctor's degree in 1602 , returned to England, and obtained the doctorate of his own university. In 1604 , he married, began practice in London, and five years afterwards became physician to St. Bartholomew's Hospital. In 1615, Harvey was elected "Professor of Anatomy and Surgery" by the College of Physicians, and his first course of lectures was delivered in 3616 . It is possible that he expounded his ideas respecting the circulation of the blood on this occasion; but, in this case, it is not obvious why he himself, in the dedication of the "Exercitatio Anatomica de Motu Cordis et Sanguinis," published in $x 628$, should not have said so. On the contrary he writes :-

"Meam de motu et usu corlis ct circuitu sanguinis sententiam E.D.D. antea sæpius in prælectionibus meis anatomicis aperui novam; sed jam per novem et amplius annos multis ocularibus demonstrationibus in conspectu vestro confirmatam, rationibus et argumentis illustratam, et $\mathrm{ab}$ objectionibus doctissimorum et peritissimorum anatomicorum liberatam, toties $\mathrm{ab}$ omnibus desideratam, à quibusdam efflagitatam, in lucem et conspectum omnium hoc libello produximus."

Why "jam per novem et amplius annos," if he had really taught the circulation "per duodecim annos?" Harvey is so careful a writer that I cannot doubt he had a meaning in the use of the particular words he has adopted, and that he did not wish to lay claim to having enunciated his complete views before 1618 or 1619 .

However this may be, the famous treatise itself was not given to the public until 1628 , and its appearance conferred upon its author a fame which rapidly extended over the civilised world. James the First died in 1625, and it is, on the whole, pleasant to reflect that Harvey owed nothing to that foul pedant. But his son was a man of a different stamp, and whatever the verdict on his political deeds may be, shines as one of the few English sovereigns who have shown an enlightened sympathy with letters,

${ }^{x}$ The portrait of Harvey will be presented to our readers in one of the May numbers of NATURE. Though every facility has been afforded by the College of Physicians, there has been unavoidable delay in its preparation. E.

VOL. XVII.-NO. 439 with science, and with art. Harvey became Charles the First's physician about 1632 , and the monarch repaid the real respect and affection with which his eminent subject evidently regarded him, in the only way for which Harvey was likely to care; namely, by doing his best to aid him in his investigations, and taking a cordial and intelligent interest in them.

Between $I_{6} 30$ and 1632 , Harvey travelled on the Continent with the young Duke of Lennox; and, in 1636 , he was physician to the Earl of Arundel's embassy to the Emperor. During this visit, he is said to have tried to convince Caspar Hofmann, of Nuremberg, of the circulation of the blood, experimentally, but in vain. When the troubles between the King and the Parliament broke. out, Harvey accompanied his master in his campaigns He was at the battle of Edgehill, in charge of the Prince of Wales and the Duke of York; and he told Aubrey that " he withdrew with them under a hedge, and tooke out of his pockett a booke and read. But he had not read very long before a bullet of a great gun grazed on the ground neare him, which made him remove his station."

By the King's order, Harvey was elected Warden of Merton College; Oxford, in 1645; and to the same efficient cause, or to the fact that he was the King's physician, we must probably look for the conference of an honorary degree by the University of that day on a mere scientific discoverer. But, after the surrender of Oxford in the following year, Harvey retired from public life altogether, and spent the remainder of his days at the homes of one or other of his brothers, in the neighbourhood of London.

In 1649 Harvey, published his two letters to Riolan, which form a supplement to the "Exercitatio Anatomica;" and, in $165 \mathrm{I}$, when he had reached the ripe age of seventy-three, the "Exercitationes de Generatione" appeared. "The rest is silence," save a few letters. In the last of them we have, dated April 24, 1657 , he writes to Vlackveld:-

"Frustra autem calcar mihi addis, ut in æatate hac, non solum matura, sed etiam fessa, ad aliquid noviter moliendum me accingam. Videor enim jam mihi, meo jure, rudem deposcere."

No man had a better right to claim an honourable discharge from duty. Six weeks later the wished-for release arrived, and on June 3 ,

Spectatum satis et donatum jam rude,

Harvey died in the eightieth year of his age, full of honours as of years, more than sufficiently wealthy, and able long before his death, to say that the great truth he had discovered and taught was accepted by all whose opinion was worth having. ${ }^{1}$

The only works which Harvey published are the famous treatise on the Circulation (I628), with the two letters to Riolan (1649), and the "Exercises on Generation (165I)." But he was a most diligent observer and writer, and he incidentally refers to a "Disquisition on the Causes and the Organs of Respiration," to "Medical Observations," to a treatise "On the Generation of Insects," and to many observations on Comparative I "Circuitum sanguinis admirabilem, a me jampridem inventum, video propemodum omnibus placuisse : nec ab aliquo quippiam hactenus objectum esse, quod responsum magnopere mereatur. '- Exercitationes de Genteratione, Ex. lii. 
Anatomy, the whole of which appear to have been destroyed when his house was plundered with the connivance, if not by order, of the Parliament, during his absence from London with the King.

Of the "Exercitatio de Motu Cordis et Sanguinis," I have treated so fully elsewhere ${ }^{1}$ on a recent occasion, that I will again not touch upon the subject except so far as to repeat that, in my judgment, Harvey is entitled, beyond dispute, to be regarded as the sole discoverer of the circulation of the blood, and of the method of its propulsion by the heart.

The story of the extraction of the manuscript of the "Exercitationes de Generatione" from Harvey is well told by Ent, who undertook the charge of seeing the work through the press; a task of no small magnitude if we consider the soperlative badness of the extant specimens of Harvey's haindwriting.

The preface contains a singularly interesting disquisition on scientific method; and, among other observations the following, which is, perhaps, the weightiest in small compass ever laid before the student of physical science.

"For those who read the words of authors, and to whom impressions of their own senses do not represent the things signified by those words, conceive, not true ideas, but falsæ eidola and inane phantoms; whence they fill their minds with shadows and chimaeras, and their whole theory (which they think to be science) represents but a waking dieam or a sick xnan's delirium."

As in the case of the circulation of the blood, the scientific opinions of the day respecting the conditions of generation and the embryogenic process had descended from the Greeks. No one doubted that a large proportion of the lower forms of life owed their origin to equivocal or spontaneous generation, or, as it is now termed, abiogenesis ; and, with respect to sexual generation, it was believed that the embryo originated at the time of sexual union, by the combination of two substances poured out ad hoc, the one being derived from the female, the other from the male parent. In this opinion both Aristotle and the Medici, following Galen, agreed; but they differed in the view which they took as to the nature and function of the two sexual elements. According to Aristotle, the female supplied merely the material of the embryo, by the excretion of a substance which he regarded as the purest part of the catamenial blood; this was coagulated, and endowed with the faculty of developing into an organism, by the spermatic fluid, of the male. The Medici, on the other hand, considered that the female produced a true spermatic fluid, analogous to that of the male, and having an equal formative energy; and indeed, that the sex of the embryo was determined by the predominance of the one or the other spermatic fluid.

As regards the embryogenic process itself, the Greeks had studied the development of the chick, and had learned somewhat respecting the fotal state of viviparous animals; while, since the revival of learning, several important embryological investigations had been undertaken. of these the most notable were those of Aldrovandus, of Coiter, of Harvey's master, Fabricius of Aquapendente, of Vesling, and of Parisanus, on the development of the chick. Fabricius' treatise, "De Ovo et Pullo," was accompanied x "William Harvey," Fortuightiy Rewicu, Felunaty i, 3878 . by figures of the stages of development, which, for the time, must be termed very good ; and it served Harvey as a sort of text-book, to which he constantly refers.

The "Exercitationes" show no advance on the knowledge of the ancients respecting the conditions of generation. Innumerable passages show that Harvey believed, as firmly as his predecessors and contemporarics did, in equivocal generation. ${ }^{1}$ The persistent ascription to Harvey of the contrary opinion is simply astounding, and can only be explained on the supposition that those who quote what they are pleased to call "Harvey's aphorism," "Omne Vivum ex Ovo," against the holders of the doctrine of spontaneous generation, have never read the works of their authority.

I cannot discover the exact phrase "omne vivum ex ovo" anywhere in Harvey's works, though it is true that the sense of the words is expressed by him over and over again. But the context shows his meaning to be, not the assertion of the doctrine of biogenesis; but simply a declaration that, in whatever way a living being is generatcd, the nature which it at first possesses is that of an egg. And what Harvey wants to impress, by the frequent iteration of his opinion on this subject, is the difference between his view, that a germ is something which comes into existence more or less as a unit and has an indivicluality of its own, and that of his predecessors, who held that it is formed by the coalescence of separate entities. Nevertheless, there is an indication that Harvey was on the right track in respect of the question of spontaneous generation; and that, if his papers on the generation of insects had not been destroyed, he might have anticipated Redi ; for the forty-first exercise contains the following remarkable passage :-

"But on these matters generally we shall have much to say, when we shall show that many animals, especially insects, take their origin and are generated from elements and sceds so small as to escepe observation (like atoms floating in the air), which are scattered and dispersed hither and thither by the winds; yet these animals are supposed to arise spontaneously, or from putrefaction, because their germs are nowhere to be found."

It was exactly this thesis that Redi adopted and proved to demonstration, seventeen years afterwards, and therefore long before Harvey's death ; and it is by following up the same line of argument that modern investigators have deprived abiogenesis of its last supposed experimental evidence. In whatever way, however, the germ of a plant or of an animal is produced it is the equivalent of an egg, and what Harvey means by an egg is clearly shown, in the following as in many other passages:-

"In the generation of all living things (as we have said) this is established, that they arise from some primordium (primordio aliquo) which contains not only the matter but the power of generation; and is, therefore, that out of which and from which the thing generated takes its origin. Such a primordium in animals (whether they proceed from parents, or arise spontaneously or out of putrefaction) is a humour contained in a membrane of some kind, or shell ; in fact, a homogeneous body (corpus nempe similare) possessing life, either actually or poten-

II pointed this out twenty years ago in my "Lectures on General Natural History," published in the Mectical Times and Gazette. Take one passage out of fifty that wight be cited: "Atque etiam terra su hwe taken this sentence for a motto. 
tially. This primordium, if it is generated within an animal and remains there, until a like animal (univocum) is produced, is vulgarly called a conception; if, however, it: s thrust out by parturition, or if it has originated elsewhere by chance, it is termed an ovum or vermis. I think, however, that, in either case, that from which an animal arises should be called primordium; just as plants produce their young from seeds; and that all these primordia are of one kind, namely, living things.

"I find a primordium of this sort in the uterus of all viviparous animals, before any fotus can be discerned. In fact, there is a clear, viscid, white [colourless] fluid, like the white of an egg, inclosed in a membrane, which I term the egg of these animals; and, in red-deer and fallow deer, in sheep and other cloven-footed animals, it fills the whole uterus and both its cornua." I

It will be observed that, in the foregoing passage, Harvey insists upon one main quality of the primordium, namely, that it is a corpus similare; or, in other words, that it is relatively homogeneous; and, in the seventy-second exercise, "De humido primogenio," he insists strongly on what he believes to be the fact that the embryo takes its rise in a certain "humidum radicale et primigenium," "simplicissimum, purissimum et sincerissimum corpus," in which all the parts of the embryo are present potentially, but not actually, and out of which they arise by a graciual process of differentiation.

"The first rudiment of the body is a mere homogeneous anci soft jelly, not unlike a spermatic coagulum, which, becoming changed (in accordance with the law of generation) and at the same time split or divided into many parts, as by a divine command, as we have said (let bone arise here, muscle or nerve there, here viscera, there receptacles of excretion, \&c.) out of the inorganic arises the organic, out of the similar the dissimilar; out of the one and the same nature, many things of diverse and of contrary natures; not, indeed, by any transposition or local motion (as when by the power of heat homogeneous things unite, or heterogeneous things are separated), but rather by the disaggregation of homogeneous things, than by the aggregation of heterogeneous things." 2

In this passage, as in those in which he advocates cpiginesis, Harvey shows a complete grasp of the great truth that development is a gradual process of change from relative homogeneity to heterogeneity, put into such clear light in our own time by Meckel and von Baer.

Again, when Harvey dwells upon the close resemblance of the early conditions of the higher animals, and accounts for harelip as a retention of an embryonic condition, we see him hovering on the brink of some of the most important embryological generalisations of a century and a half after his time.

After Harvey, embryological theory distinctly" retrograded for a full century, until, in fact, a hundred and eight years had elapsed, and, in 1759, Caspar Friedrich Wolff published his "Theoria Generationis." In the

I "De Uteri Membranis et Humoribus." Elsewhere (Exercitatio xxvi.) Harvey says:-

"Ovum itaque est corpus naturale, virtute animali præditum: principio nempe motûs, transmutationis, quietis, et conservationis. Est denique ejusmodi, ut, ablato omni impedimento, in formam animalis abiturum sit; nec magis naturaliter gravia omuia, remotis obstaculis, deorsum tendunt; aut lievia sursum moventur: quàm semen et ovum in plantam aut animal, insita i naturâ propensione, feruntur. Łstque semen (atque etiam ovum) ejusdem fructus et finis, cujus est principium atque efficiens.

actus et finis, "cujus est principium atque interval, the great truths laid down by Harvey, that ali germs are homogeneous relatively to the forms to which they give rise, and that all those of the higher animals, at any rate, pass by cpigenesis into the perfect living thing-"Fabrica a parte aliqua tanquam ab origine incipit : ejusque ope reliqua membra adsciscuntur : atque haec per epigenesin fieri dicimus: sensim nempe partem post partem: estque isthæe, præaltera, proprie dicta generatio" (Exercitatio xiv.); these verities, justified by all our present knowledge, were ignored, and the doctrine of the "pre-existence of germs" and of "evolution" took their place. And so strong was the hold of the latter, that even Wolff's conclusive investigations produced little effect, and the full acceptance of Harvey's generalisations dates from the last half-century.

But while Harvey's views respecting the general nature of the embryogenic process were as much in advance of his time as were his doctrines respecting the motion of the heart and the circulation of the blood, his demonstration of them is a failure, the phenomena being too subtle and recondite for the means of investigation which he possessed.

So far as the process of fecundation is concerned, he is further from the truth than were the Greeks; for he steadily denies that the male element enters into the substance of the egg, or even comes into physical contact with it; and he ascribes the efficacy of the male to a sort of contagion, by which the female organism is infected, and in consequence of which, the ova, which he justly declares to be formed like any other growth, acquire the property of developing into embryos.

Again, though Harvey's discovery, that the region of the cicatricula in the hen's egg is the seat of the changes which give rise to the embryo, was of primary importance, he has not the least notion of the real nature of the cicatricula or of its relations to the yolk. The "primigenial radical humour," which he supposes to be the first commencement of the embryo, is nothing but the amniotic fluid, which is really formed long after the rudimentary body of the chick has appeared. And Harvey's supposition that the blood is that which is first formed and that the substance of the body grows round the vessels "like a mucor or fungus," is an error, which is, of course, enormous, and may seem unpardonable to any one who has not tried to make out the early stages of the development of the egg with the naked eye, or even aided by a hand-glass. It was the discovery that the rudiment of the body of the chick exists in the egg, long before Harvey supposed, that was one of the chief causes of the adoption of the notion of the pre-existence of germs which led to the "evolution" and "emboitement" hypotheses. Buffon, in fact, went so far as to say that the chick " exists fully formed (en entier) in the middle of the cicatricula when the egg leaves the body of the fowl," " thereby erring as far as Harvey did, but in the opposite direction.

After due deduction is made for these errors and shortcomings, however, the great merit of having been the first to grasp the true principle of interpretation of the process of development, must, I think, be accorded to Harvey; and if we consider the part which the study o development has played, and must henceforward continue I Buffon, "Histoire Naturelle," t. ii., ed. 2 , r750, p. 35 r. 
to play in biology, the "Exercitationes cle Generatione," though second to the "Exercitatio Anatomica," can hardly be said to have another rival in the contemporary literature of biological science.

Modern morphology, no less than physiology, has its root in the work of William Harvey. T. H. HUXLEY

\section{ZÖLLNER'S SCIENTIFIC PAPERS}

Wissinschaftliche Abhanullungen (Erster Band). Von F. Zöllner. (Leipzig : L. Staackmann, 1878.)

$\mathrm{IF}$ we take a somewhat different course in reviewing 1 this work from that which we should naturally adopt with works professedly scientific, we hope at least to justify our conduct to the reader before we finish. Fur, alas, all is not scientific that professes to be science, and even celestial minds can harbour very curious feelings and express them with most unmistakeable vigour, while not always striking above the belt.

The key-note of this work, as well as of a great deal of the other somewhat voluminous writings of Prof. Zöllner, is struck by himself in a foot-note to p. 129 , where he tells us that "the aim of ail his scientific efforts has been to contribute, as far as the ability given him permits, to the realisation" of a certain "hopeful project":-viz., the explanation of all molecular actions by means of that Law of Electric Attraction (due to $W$. Weber) which "has already been so fruitul in cöordinating under one principle all electric and magnetic phenomena."

Very good and laudable :--though we may permit ourselves to say, in passing, probably very unpromising. But it is quite impossible to say what hints a competent mathematician may not obtain while he is attempting to prosecute the applications of any theory-however remote its principles may be from those which the experimental facts themselves suggest to the physical investigator in his laboratory. Unfortunately even this concession is thrown away upon Prof. Zöllner :-for he not only does not claim to be considered as a mathematician, but hats on a former occasion (in his work on Comets) expressly denounced those who attempt "by differentiating and integrating " to get at natural laws. He is, as Helmholtz long ago said, a genuine Metaphysician, and (as such) is a curiosity really worthy of study :- not of course mercly because he is a Metaphysician, but because in this nineteenth century he attempts to bring his metaphy sics into pure physical science.

To a man whose whole object in scientific life is the establishment of Weber's Law as the fundamental facc of the Kosmos, of course all works are an Abomination in which even an attempt is made to show that action at a distance can be (and therefore ought to be) dispensed with. Hence Clerk-Maxwell's Theory, which, even its opponents must allow, has succeeded at least as well as Weber's in connecting and explaining the phenomena of electricity; magnetism, and light, must be demolished at all hazards. But the reader of Maxwell's great work on Electricity, who has seen in its very Preface that the main object of that work was to carry out to their legitimate mathematical developments the physical ideas of Faraday, will scarcely be prepared to find that Prof. Zöllner accepts Faraday and denounces Maxwell !

This tour de force is worthy of so accomplished a meta- physician. It is absulutely refreshing in its coolness! According to Prof. Zöllner, both Clerk-Maxwell and Sir W. Thomson (to whose advice the former owns his indebtedness) quote Faraday correctly, and yet altogether misapprehend his meaning! In fact we are now told, though not in so many words, that Faraday, whom we had all looked on as an opponent of action at a distance, was really a firm believer in it, and a strenuous advocate of it ! Not only Faraday, but even Newton himself :-in spite of the celebrated Letters to bentley, in which all of us have hitherto read the inconceivability of distanceaction to any mind which "has in philosophic matters a competent faculty of thinking "-even Newton himself, it seems, believed in action at a distance!

On this no farther comment is necessary than one I made some time ago, when Prof. Zöllner, to his own satisfaction at least, proved me to te jgnorant alike of Latin and of the very First Law of Molion,--viz, that "Prof. Zöllner should not atternpt to criticise... until he acquircs sufficient knowledge of British technical terms ..."

That a good deal of I'rof Zöllner's censure is due to his imperfect apprehension of English, will, I think, be allowed by every candid reader. I say nothing of numerous misspellings--sometimes ludicrous, such as " in his sobber (sic) sinses" -which occurs twice at least (pp. $\mathrm{I}_{42}$, 711 ), because there are quite as many misspellings in the German, and a!l are, therefore, probably due to the printer. But it is a wonclerful piece of information for us benighted islanders to be told that our foremost scientific men, while quoting Newton accurately, entirely miss, or rather misrepresent, his meaning. So wonderful that I certainly shall not be believed, unless I refer definitely to some of the inculpatory passages :-

[The passage ( $\mu$ p. $14{ }^{1-152}$ ) is too lon for franslation, so I give a small part only; restricting myself to the tone in which British authors are spoken of, for the substatice of the accusation, such as it is, has been already indicated.]

"One's impaired power of discovering contradictions prevents his recognising them as such even when the effect of the contrast is heightened by juxtaposition. Hence we must ascribe the non-retractation of such by their authors not to moral weakness but to incapacity. Hence also the surprising naiveté with which such men (i.e., Sir W. Thomson, Clerk-Maxwell, ct hoc genus omne) hand over to their critic the weapons with which to exterminate them, \&c., \&c. He who thinks it superfluous to bother himself with the thoughts of his predecessors and contemporaries loses ipso facto all right to consideration for himself and his writings. Such an author will in after time be forgotten, just as he has forgotten bis predecessors, and this in the name of Eternal Right. For, only in the continuity of the mental work of successive generations is there security for the progress of Humanity!"

The reader of this will perhaps think that he has seen enough of Prof. Zöllner and his work :-enough at least to enable him to form a pretty shrewd guess as to the scientific value of the whole. But I must be excused if I trouble him with a few additional remarks on another aspect of the book.

Some years ago Prof. Helmholtz kindly undertool: to revise the German translation of Thomson and Tait's Natural Philosophy, and was in consequence somewhat 